\title{
ANALISIS USAHA PEMBIBITAN PUYUH PERSILANGAN JEPANG (Coturnix coturnix japonica) DENGAN PUYUH HYBRID SECARA INTENSIF
}

\author{
Eka Julaiha $^{1}$ Muhammad Daud ${ }^{1 *}$ M. Aman Yaman ${ }^{1}$ \\ ${ }^{1}$ Program Studi Peternakan, Fakultas Pertanian, Universitas Syiah Kuala
}

\begin{abstract}
Abstrak. Puyuh merupakan salah satu jenis unggas yang memiliki potensi untuk dikembangkan dan ditingkatkan produksinya. Selain menghasilkan daging, puyuh juga menghasilkan telur untuk memenuhi kebutuhan protein hewani bagi masyarakat. Salah satu faktor yang mempengaruhi keuntungan usaha serta produksi telur puyuh adalah bibit. Banyaknya peternakan puyuh yang melakukan pembibitan sendiri menyebabkan perkawinan puyuh tidak terkendali dan cenderung terjadinya perkawinan sejenis (inbreeding) yang menyebabkan mutu genetik puyuh menurun. Salah satu cara untuk memperbaiki mutu genetik ternak puyuh perlu dilakukannya perkawinan silang secara (Crossbreeding) yang diharapkan dapat memperbaiki mutu genetik serta memberikan keuntungan. Tujuan dari penelitian ini adalah untuk mengetahui kelayakan usaha pembibitan puyuh Jepang (Coturnix coturnix japonica) dengan Hybrid yang dipelihara secara intensif. Hasil penelitian menunjukkan bahwa usaha pembibitan puyuh persilangan memberikan keuntungan pada perlakuan P1 didapatkan pendapatan sebesar Rp. 93.376,- sedangkan P2, sebesar Rp. 98.197, P3, sebesar Rp. 92.158,- dan pada perlakuan P4, sebesar Rp. 103.053,- dengan analisis kelayakan usaha yang didapatkan mempunyai prospek yang baik dan layak untuk dijadikan usaha. Pada perlakuan P1 dan $\mathrm{P} 2$ dengan nilai $\mathrm{R} / \mathrm{C}$ ratio 1.4 sedangkan pada perlakuan $\mathrm{P} 3$ nilai $\mathrm{R} / \mathrm{C}$ ratio adalah 1.3 dan pada perlakuan $\mathrm{P} 4$ mendapatkan nilai $\mathrm{R} / \mathrm{C}$ ratio 1.3 . Dengan perhitungan $\mathrm{B} / \mathrm{C}$ ratio pada perlakuan $\mathrm{P} 1$ dan $\mathrm{P} 2$ didapatkan nilai 0.4 , sedangkan pada perlakuan $\mathrm{P} 3$ dan $\mathrm{P} 4$ didapatkan nilai $\mathrm{B} / \mathrm{C}$ ratio 0.3.
\end{abstract}

Kata Kunci: Bibit puyuh, Inbreeding, Crossbreeding, Keuntungan usaha, Kelayakan usaha

Abstrack. Quail is one type of bird that has the potential to be developed and increased production. In addition to producing meat, quail also produces eggs to meet the needs of animal protein for the community. One of the factors that influence business profits and the production of quail eggs is seeds. The large number of quail farms that do their own breeding cause uncontrolled quail marriage and tend to occur inbreeding which causes the genetic quality of quail to decline. One way to improve the genetic quality of quail cattle is to do crossbreeding which is expected to improve genetic quality and provide benefits. The purpose of this study was to determine the feasibility of Japanese quail nursery business (Coturnix coturnix japonica) with Hybrid which is maintained intensively. The results of the study showed that the breeding of quail crosses gave advantages in treatment P1, the income of Rp. 93,376, - while P2, Rp. 98,197, P3, amounting to Rp. 92,158, - and in treatment P4, Rp. 103,053, - with a business feasibility analysis obtained having good prospects and worthy of being a business. In treatment P1 and P2 with the value of $\mathrm{R} / \mathrm{C}$ ratio 1.4 while in treatment $\mathrm{P} 3$ the value of $\mathrm{R} / \mathrm{C}$ ratio is 1.3 and in treatment $\mathrm{P} 4$ get the value of $\mathrm{R} / \mathrm{C}$ ratio 1.3. With the calculation of $\mathrm{B} / \mathrm{C}$ ratio in treatment $\mathrm{P} 1$ and $\mathrm{P} 2$ obtained a value of 0.4 , while the treatment $\mathrm{P} 3$ and $\mathrm{P} 4$ obtained the value of $\mathrm{B} / \mathrm{C}$ ratio 0.3 .

Keywords: quail seeds, inbreeding, crossbreeding, business benefits, business feasibility

Corresponding author: Daewood@unyiah.ac.id

JIM Pertanian - PET, Vol. 4, No. 1, Februari 2019: 486-494 


\section{PENDAHULUAN}

Puyuh merupakan salah satu jenis unggas yang memiliki potensi untuk dikembangkan dan ditingkatkan produksinya. Selain menghasilkan daging, puyuh juga menghasilkan telur untuk memenuhi kebutuhan protein hewani bagi masyarakat. Puyuh merupakan unggas daratan yang memiliki ukuran tubuh yang kecil, pemakan biji-bijian dan serangga kecil. Jenis puyuh yang sering dibudidayakan adalah puyuh jepang (Coturnix coturrnix japonica) karena puyuh ini mulai berproduksi pada umur 35-42 hari. Puyuh betina mampu menghasilkan 250300 butir telur dalam setahun dengan berat telur sekitar 9-13 gram/butir atau 7,8 dari bobot badan.

Salah satu faktor yang mempengaruhi keuntungan usaha serta produksi telur adalah bibit. Banyaknya peternakan puyuh yang melakukan pembibitan sendiri menyebabkan perkawinan puyuh tidak terkendali dan cenderung terjadinya perkawinan sejenis (inbreeding). Peternak melakukan perkawinan secara terus menerus pada satu jenis puyuh, sehingga semakin lama produksi ternak puyuh yang dihasilkan dari perkawinan tersebut akan semakin menurun produksinya.

Salah satu cara untuk mencegah perkawinn in-breeding dengan melakukan perbaikan genetik ternak puyuh melalui perkawinan silang antara puyuh lokal yaitu puyuh jepang (Coturnix coturnix japonica) dengan puyuh Hybrid yaitu puyuh yang berasal dari persilangan antara puyuh jantan lokal (Puyuh Hutan) dengan puyuh betina jepang (Coturnix coturnix japonica) dari Slamet Quail Farm (SQF) Suka Bumi, Jawa Barat. Persilangan yang dilakukan dengan tujuan memperbaiki peformance produksi bibit ternak puyuh, baik dalam hal meningkatkan produksi telur puyuh atau tingkat konversi ransum yang rendah. Melalui proses perkawinan silang diharapkan menghasilkan bibit puyuh baru yang berkualitas, sehingga usaha yang dijalankan dapat memberi keuntungan.

\section{Waktu Penelitian dan Tempat}

\section{MATERI DAN METODE}

Penelitian ini dilakukan di Laboratorium Lapangan Peternakan (LLP), Program Studi Perternakan, Fakultas Pertanian, Universitas Syiah Kuala, Darussalam, Banda Aceh, selama 36 hari mulai tanggal 02 Juli - 06 Agustus 2018.

\section{Alat dan Bahan}

- Alat

Peralatan yang digunakan pada penelitian ini meliputi kandang besi bertingkat yang terdiri dari 16 kotak berskat, mesin tetas (thermostat), brooding (DOQ), lampu pijar, timbangan, alat semprot, tempat pakan dan tempat minum, triplek, alat tulis dan buku catatan ( Recording).

\section{- Bahan}

Bahan-Bahan yang digunakan pada penelitian ini terdiri, pakan dan 324 1-M, egg stimulant, air minum bersih, serta perlengakapan sanitasi seperti (rodalon, kapur dan detergen).

\section{Materi Penelitian}


Materi yang digunakan dalam penelitian ini adalah 40 ekor puyuh jantan Hybrid dan 64 ekor betina puyuh Jepang (Coturnix coturnix japonica. Puyuh jantan Hybrid di yang di pesan pada salah satu breeding farm yang berada di Ajun dan Montasik (Aceh Besar).

\section{Analisis Penelitian}

Penelitian ini menggunakan Rancangan Acak Lengkap dengan 4 perlakuan dan 4 ulangan yang masing-masing perlakuan menggunakan perbandingan yang terdiri dari 1 puyuh jantan Hybrid dengan 4 puyuh betina jepang (1:4), 2 puyuh jantan Hybrid dengan 4 puyuh betina Jepang (2:4), 3 puyuh jantan Hybrid dengan 4 puyuh betina Jepang $(3: 4)$, dan 4 puyuh jantan Hybrid dengan 4 betina Jepang (4:4).

\section{Prosedur Penelitian}

\section{- Tahap Persiapan}

Tahap ini meliputi persiapan kandang, pakan, serta peralatan kandang. Kandang yang digunakan adalah kandang bateri yang sudah di skat-skat menurut perlakuan dan ulangan, kandang baterai yang digunakan berbahan besi yang terdiri dari 4 tingkat, sebelum melakuan penelitian kandang baterai serta lingkungannya dibersihkan terlebih dahulu dari berbagai jenis kotoran dan bibit penyakit serta sampah-sampah dan rumput yang berada dilingkungan kandang. Setelah kandang dan semua perlengkapan kandang serta lingkungan telah bersih dari mikroorganisme selanjutnya melakukan pemesanan puyuh yang akan digunakan untuk penelitian.

\section{- Tahap Penelitian}

Tahap Penelitian yang dilakukan dengan cara mengawinkan puyuh dewasa kelamin yang sudah diseleksi terlebih dahulu dan timbang pada minggu pertama penelitan kemudian dimasukkan kedalam kandang menurut perlakuan dan ulangan yang sudah diberikan. Setelah semua skat terisi kemudian mengisi tempat pakan dan tempat minum yang sudah dibersihkan terlebih dahulu. Pakan yang diberikan sebanyak 25 gr/ekor/hari, setelah itu dilakukan penimbangan pakan dan berat badan dilakukan setiap minggunya untuk mengetahui jumlah konsumsin pakan puyuh lekor/hari serta berat badan.

Pemberian pakan dan minum dilakukan satu kali pada pagi hari jam 07-08 Wib. Pemberian air minum dilakukan secara adlibitum (tidak terbatas), tempat minum yang digunakan pada penelitian ini adalah tempat minum anak ayam yang berkapasitas 1 litter dengan penambahan Egg Stimulant didalamnya. Pemberian Egg Stimulant dilakukan dengan perbandingan 3:1 yaitu 3 kali pemberian berturutturut dengan penambahan Egg Stimulant maka hari selanjutnya hanya memberikan air putih saja. Hal itu dilakukan sampai penelitian selesai.

Tahap selanjutnya yang dilakukan pada penelitian ini adalah melakukan recording telur setiap hari pagi dan sore, pemungutan telur dilakukan 2 kali yaitu pagi dan sore. Pada penelitian ini masa pengumpulan untuk telur tetas dilakukan selama 3 hari untuk satu kali penetasan, telur yang tidak lulus seleksi kemudian di jual ke pasar dengan harga mengikuti harga dipasaran pada saat penelitian 
berlangsung. Tahap selanjutnya dilakukan penetasan telur dengan suhu $38-38,5^{\circ} \mathrm{C}$, dan kelembaban 60-70\%, dengan melakukan pembalikan telur 3 kali sehari yaitu pagi, siang, dan sore. Setelah telur yang ditetaskan menetas DOQ dimasukkan ke dalam kandang brooding yang sudah disiapkan sebanyak 16 unit yang terdiri dari masing-masing perlakuan dan ulangan dan kemudian dipasarkan, terakhir melakukan pemasaran puyuh afkir kepada salah satu breeding farm yang berada di Montasik Aceh besar dan kemudian dilakukan pengumpulan data penelitian.

\section{Biaya Produksi}

\section{HASIL DAN PEMBAHASAN}

Biaya produksi adalah seluruh biaya yang dikeluarkan selama proses pemeliharaan puyuh itu berlangsung yang terdiri dari biaya tetap dan biaya variabel. Hasil perhitungan biaya produksi selama penelitian (5 minggu) tercantum pada Tabel 1.

Tabel 1. Biaya Produksi Usaha Pembibitan Puyuh Selama 1 Periode (5 Minggu)

\begin{tabular}{lllll}
\hline \multirow{2}{*}{ Komponen Biaya } & \multicolumn{3}{c}{ Perlakuan } & \\
\cline { 2 - 5 } & \multicolumn{1}{c}{ P1 } & P2 & P3 & P4 \\
\hline Perhitungan Biaya Tetap & 3.605 & 4.326 & 5.047 & 5.768 \\
Sewa Kandang & 208.2 & 249.84 & 291.48 & 333.12 \\
Sewa mesin tetas & 1.950 & 2.340 & 2.730 & 3.120 \\
Peralatan Kandang & 5.763 & 6.915 & 8.068 & 9.221 \\
\hline Jumlah Biaya Tetap & & & & \\
\hline Perhitungan Biaya Variabel & 64.000 & 64.000 & 64.000 & 64.000 \\
\hline Puyuh indukan (Betina) & 16.000 & 32.000 & 48.000 & 64.000 \\
Puyuh Pejantan & 91.313 & 109.894 & 125.764 & 147.593 \\
Pakan & 2.640 & 3.168 & 3.696 & 4.224 \\
Vitamin & 13.500 & 16.200 & 18.900 & 21.600 \\
Tenaga Kerja & 6.530 & 7.836 & 9.142 & 10.448 \\
Sanitasi & 193.983 & 233.098 & 269.502 & 311.865 \\
\hline Jumlah Biaya Variabel & 199.746 & 240.013 & 277.570 & 321.086 \\
\hline Biaya Total Produksi & & & & \\
\hline
\end{tabular}

Keterangan:

P1: Persilangan puyuh jantan Hybrid dan betina Jepang (Coturnix coturnix japonica) (1:4)

P2: Persilangan puyuh jantan Hybrid dan betina Jepang (Coturnix coturnix japonica) (2:4)

P3: Persilangan puyuh jantan Hybrid dan betina Jepang (Coturnix coturnix japonica) (3:4)

P4: Persilangan puyuh jantan Hybrid dan betina Jepang (Coturnix coturnix japonica) (4:4)

Berdasarkan Tabel di atas menunjukkan bahwa total biaya produksi yang dikeluarkan pada usaha pembibitan puyuh persilangan (Coturnix coturnix japonica) dengan puyuh Hybrid selama 5 minggu penelitian yang dihitung menurut per

Analisis Usaha Pembibitan Puyuh persilangan Jepang (Coturnix coturnix japonica) 489 dengan Puyuh Hybrid secar Intensif (Eka Julaiha, Muhammad Daud, M. Aman Yaman) JIM Pertanian - PET, Vol. 4, No. 1, Februari 2019: 486-494 
perlakuan memperoleh hasil yang berbeda, yaitu: pada perlakuan P1 memperoleh hasil total biaya produksi sebesar Rp. 199.746.,- P2 sebesar Rp 240.013.,sedangkan P3, sebesar Rp. 277.570.,- dan P4, sebesar Rp. 321.086,-. Biaya produksi terendah yang diperoleh pada penelitian ini terdapat pada perlakuan P1 yaitu sebesar Rp. 199.746 dan total biaya produksi tertinggi terdapat pada perlakuan P4 yaitu sebesar Rp. 321.086,-. Perbedaan biaya produksi pada setiap perlakuan dikarenakan jumlah puyuh yang dilakukan perkawinan silang berbeda, sehingga dapat mempengaruhi biaya total produksi yang dikeluarkan.

\section{Biaya Tetap (Fixed Cost)}

Hasil perhitungan biaya tetap pada Tabel di atas menunjukkan hasil yang berbeda, tergantung pada perlakuan yang diberikan. Biaya tetap pada perlakuan P1 sebesar Rp. 5.763,-, perlakuan P2 sebesar Rp. 6.915,- perlakuan P3 sebesar Rp. 8.068,- dan perlakuan P4 sebesar Rp. 9.221,- Nilai biaya tetap tertinggi terdapat pada perlakuan P4 dan nilai terendah terdapat pada perlakuan P1. Perbedaan nilai dari biaya tetap pada penelitian ini disebabkan karena jumlah puyuh yang terdapat pada perlakuan berbeda. Hal ini didukung oleh pernyataan Anugerah et al. (2009), bahwa jumlah populasi puyuh yang dipelihara memberikan pengaruh terhadap jumlah biaya tetap (kandang dan peralatan) yang dikeluarkan. Hasil perhitungan pada penelitian ini biaya tetap tertinggi terdapat dari biaya sewa kandang.

\section{Biaya Variabel}

Hasil penelitian menunjukkan biaya variabel tertinggi terdapat pada perlakuan P4 yaitu Rp 316.185,- dan biaya variabel terendah terdapat pada perlakuan P1 yaitu Rp. 196.683,- . Perbedaan biaya variabel dikarenakan jumlah puyuh yang berbeda pada setiap perlakuan sehingga mempengaruhi biaya pengeluaran untuk pembelian pakan. Hal ini juga sama dengan pernyataan dari Zentiko et al. (2015), yang menyatakan bahwa biaya variabel merupakan biaya berubah-ubah yang besar kecilnya tergantung pada skala usaha atau aktivitas produksi, maka semakin banyak jumlah puyuh yang dipelihara akan semakin besar biaya yang dikeluarkan.

Biaya variabel merupakan biaya terbesar yang dikeluarkan pada usaha pembibitan puyuh, salah satu penyebab tingginya biaya variabel adalah biaya pakan yang tinggi yaitu Rp 285.000.- untuk 1 sak yang mempunyai berat $50 \mathrm{~kg}$. Tingginya biaya pakan ini dikarenakan pakan puyuh yang dibeli didatangkan dari luar Aceh. Hal tersebut juga disebutkan Panekenan et al. (2013) pada jurnalnya yaitu salah satu penyebab tingginya biaya tidak tetap pada usaha ternak puyuh dikarenakan biaya pakan yang tinggi. Para peternak di kecamatan Sonder membeli pakan puyuh berharga Rp.285.000,-untuk satu sak pakan yang mempunyai berat $50 \mathrm{~kg}$.

\section{Penerimaan Usaha}

Penerimaan adalah nilai dari hasil penjualan yang dilakukan oleh peternak untuk menghasilkan uang dari suatu usaha yang dijalankan. Penerimaan dari usaha peternakan puyuh diperoleh dari hasil penjualan telur, DOQ dan puyuh afkir. Pada penelitian ini penerimaan usaha dihitung berdasarkan perlakuan yang diberikan, seperti dijelaskan pada Tabel 2 .

Analisis Usaha Pembibitan Puyuh persilangan Jepang (Coturnix coturnix japonica) 
Tabel 2. penerimaan usaha pembibitan puyuh

\begin{tabular}{|c|c|c|c|c|c|}
\hline \multirow[b]{2}{*}{ No } & \multirow{2}{*}{ Jenis Penerimaan } & \multicolumn{4}{|c|}{ Perlakuan } \\
\hline & & $\mathrm{P} 1$ & $\mathrm{P} 2$ & P3 & $\mathrm{P} 4$ \\
\hline \multirow[t]{5}{*}{1.} & Penjualan Telur & & & & \\
\hline & Jumlah telur (butir/perlakuan) & 364 & 382 & 388 & 412 \\
\hline & Harga jual telur (Rp/butir) & 350 & 350 & 350 & 350 \\
\hline & Penerimaan penjualan telur & 127.400 & 133.700 & 135.800 & 144.200 \\
\hline & Jumlah Puyuh/perlakuan (ekor) & 20 & 24 & 28 & 32 \\
\hline \multirow[t]{4}{*}{2.} & Penjualan DOQ & & & & \\
\hline & Jumlah DOQ & 19 & 26 & 28 & 38 \\
\hline & Harga/ekor(Rp) & 2.000 & 2.000 & 2.000 & 2.000 \\
\hline & $\begin{array}{l}\text { Penerimaan Penjualan DOQ } \\
(\mathrm{Rp})\end{array}$ & 38.000 & 52.000 & 56.000 & 76.000 \\
\hline \multirow[t]{4}{*}{3.} & Penjualan Puyuh Afkir & & & & \\
\hline & Jumlah puyuh afkir (ekor) & 20 & 24 & 28 & 32 \\
\hline & Harga puyuh afkir (Rp/ekor) & 6500 & 6500 & 6500 & 6500 \\
\hline & Penerimaan puyuh afkir (Rp) & 130.000 & 156.000 & 182.000 & 208.000 \\
\hline
\end{tabular}

\section{Pendapatan usaha ternak}

Pendapatan usaha adalah nilai yang diperoleh dari total penerimaan yang sudah dikurangi biaya produksi yang dikeluarkan oleh peternak dalam satu periode pemeliharaan. Pernyataan ini sejalan dengan pemikiran Roesalli (2005), bahwa Pendapatan (keuntungan) usaha diperoleh dari hasil selisih antara total penerimaan dengan semua total biaya. Adapun keuntungan yang diperoleh pada penelitian ini dapat dilihat pada tabel 3 .

Tabel 3. Keuntungan Usaha Pembibitan Puyuh Persilangan (5 Minggu)

\begin{tabular}{lllll}
\hline Perlakuan & $\begin{array}{l}\text { Biaya Produksi } \\
(\mathrm{Rp})\end{array}$ & $\begin{array}{l}\text { Penerimaan } \\
(\mathrm{Rp})\end{array}$ & $\begin{array}{l}\text { Pendapatan } \\
(\mathrm{Rp})\end{array}$ & $\begin{array}{l}\text { Keuntungan/ekor } \\
(\mathrm{Rp})\end{array}$ \\
\hline P1 & 199.746 & 295.400 & 95.654 & 4.782 \\
P2 & 240.013 & 341.700 & 101.687 & 4.236 \\
P3 & 277.570 & 373.800 & 96.230 & 3.436 \\
P4 & 321.086 & 428.800 & 107.714 & 3.336 \\
\hline
\end{tabular}

Keterangan:

P1: Persilangan puyuh jantan Hybrid dan betina Jepang (Coturnix coturnix japonica) (1:4)

P2: Persilangan puyuh jantan Hybrid dan betina Jepang (Coturnix coturnix japonica) (2:4)

P3: Persilangan puyuh jantan Hybrid dan betina Jepang (Coturnix coturnix japonica) (3:4)

P4: Persilangan puyuh jantan Hybrid dan betina Jepang (Coturnix coturnix japonica) (4:4)

Berdasarkan Tabel 3 dapat kita amati pada perlakuan P1 didapatkan pendapatan sebesar Rp. 95.654,-- sedangkan P2, sebesar Rp. 101.687, P3, sebesar Rp. 96.230,- dan pada perlakuan P4, sebesar Rp. 107.714,-. Pada penelitian ini

Analisis Usaha Pembibitan Puyuh persilangan Jepang (Coturnix coturnix japonica) 491 dengan Puyuh Hybrid secar Intensif (Eka Julaiha, Muhammad Daud, M. Aman Yaman) JIM Pertanian - PET, Vol. 4, No. 1, Februari 2019: 486-494 
perbedaan pendapatan (keuntungan) tiap perlakuan diperoleh hasil yang berbeda hal itu disebabkan karena jumlah puyuh yang dipelihara memilki jumlah yang berbeda tiap perlakuannya. Berdasarkan hasil perhitungan yang didapatkan perlakuan yang memilki jumlah puyuh yang paling banyak mendapakan tingkat pendapatan yang paling tinggi, jadi dapat dikatakan semakin banyak puyuh yang dipelihara maka akan semakin besar pendapatan yang didapatkan.

Hal tersebut sependapat dengan Panekenan (2013) yang menyatakan hal-hal yang mempengaruhi besar kecilnya pendapatan salah satunya jumlah populasi puyuh yang dipelihara, banyak atau sedikitnya jumlah ternak yang dipelihara sangat berpengaruh terhadap besar kecilnya keuntungan (laba) yang diperoleh oleh peternak. Namun untuk mendapatkan keuntungan yang optimal harus dianalisa terlebih dahulu sampai pada titik berapa banyak jumlah ternak yang baik untuk dipelihara sehingga bisa mendatangkan keuntungan yang optimal dan tidak menghasilkan kerugian.

\section{Analisis Kelayakan Usaha}

Analisis usaha mutlak dilakukan bila seseorang hendak memulai usaha.Analisis usaha dilakukan untuk mengukur atau menghitung apakah usaha tersebut menguntungkan atau merugikan. Analisis usaha memberi gambaran kepada peternak untuk melakukan perencanaan usaha. Dalam analisis usaha diperlukan beberapa asumsi dasar dapat berubah sesuai dengan perkembangan waktu (Supriadi, 2009). Untuk menilai suatu usaha, diperlukan evaluasi terutama untuk hal yang menyangkut ekonomi antara lain biaya dan pendapatan, kelayakan usaha dan analisis (Harahap, 2008).

\section{Return Cost Ratio (R/C ratio)}

Analisa R/C ratio merupakan singkatan dari Return cost ratio, atau dikenal dengan perbandingan antara penerimaan dengan total biaya produksi. Suatu usaha dapat dinyatakan layak dijalankan apabila nilai $\mathrm{R} / \mathrm{C}$ ratio diperoleh lebih dari satu yang artinya usaha yang dijalankan mendapatkan keuntungan, maka semakin besar nilai $\mathrm{R} / \mathrm{C}$ ratio maka semakin besar pula tingkat efesiensi suatu usaha. Nilai $\mathrm{R} / \mathrm{C}$ ratio diperoleh dengan cara membandingkan total penerimaan dengan total biaya produksi, berikut disajikan pada tabel 4.

Tabel 4. Analisa kelayakan Return Cost Ratio (R/C ratio)

\begin{tabular}{lllll}
\hline Indikator kelayakan & P1 & P2 & P3 & P4 \\
\hline Penerimaan & 295.400 & 341.700 & 373.800 & 428.800 \\
Biaya total produksi & 199.746 & 240.013 & 277.570 & 321.086 \\
R/C ratio & 1.4 & 1.4 & 1.3 & 1.3 \\
\hline
\end{tabular}

Keterangan:

P1: Persilangan puyuh jantan Hybrid dan betina Jepang (Coturnix coturnix japonica) (1:4)

P2: Persilangan puyuh jantan Hybrid dan betina Jepang (Coturnix coturnix japonica) (2:4)

P3: Persilangan puyuh jantan Hybrid dan betina Jepang (Coturnix coturnix japonica) (3:4)

P4: Persilangan puyuh jantan Hybrid dan betina Jepang (Coturnix coturnix japonica) (4:4) 
Berdasarkan Tabel di atas didapatkan hasil dari penelitian bahwa $\mathrm{R} / \mathrm{C}$ ratio pembibitan puyuh dengan menggunakan 4 perlakuan mendapatkan hasil $\mathrm{R} / \mathrm{C}$ ratio tertinggi terdapat pada perlakuan $\mathrm{P} 1$ dan $\mathrm{P} 2$ dengan nilai $\mathrm{R} / \mathrm{C}$ ratio 1.4 sedangkan pada perlakuan $\mathrm{P} 3$ nilai $\mathrm{R} / \mathrm{C}$ ratio adalah 1.3 dan pada perlakuan $\mathrm{P} 4$ mendapatkan nilai $\mathrm{R} / \mathrm{C}$ ratio 1.3 kondisi ini menunjukkan bahwa usaha pembibitan puyuh persilangan antara (Cotrnix-coturnix japonica) dengan puyuh Hybrid layak untuk dijadikan usaha, karena R/C ratio yang didaptakan lebih besar dari pada satu. Pernyataan ini juga disebutkan oleh Murib (2014) yang menyatakan bahwa semakin tinggi rasio usaha yang didapatkan dalam usaha peternakan, maka usaha tersebuut semakin efisiyen, bila $\mathrm{R} / \mathrm{C}$ ratio yang didapatkan lebih dari satu, berarti usaha yang dijalankan mendapatkan keuntungan.

\section{Benefit Cost Ratio (B/C ratio)}

Pada penelitian ini salah satu analisa kelayakan usaha dilakukan dengan cara menghitung $\mathrm{B} / \mathrm{C}$ ratio dengan cara membandingkan total pendapatan dengan total biaya produksi. Perhitungan $\mathrm{B} / \mathrm{C}$ ratio dilakukan untuk melihat tingkat keuntungan yang diperoleh oleh suatu usaha, sehingga usaha tersebut mendapatkan hasil layak atau tidak untuk dijalankan. Hasil perhitungan B/C ratio dapat dilihat pada tabel 5.

Tabel 5. Analisa Kelayakan Melalui Perhitungan Benefit Cost Ratio (B/C Ratio)

\begin{tabular}{lllll} 
Indikator Kelayakan & $\mathrm{P} 1$ & $\mathrm{P} 2$ & $\mathrm{P} 3$ & $\mathrm{P} 4$ \\
\hline Pendapatan (Rp) & 95.654 & 101.687 & 96.230 & 107.714 \\
Biaya Total Produksi (Rp) & 199.746 & 240.013 & 277.570 & 321.086 \\
B/C Ratio & 0.4 & 0.4 & 0.3 & 0.3 \\
\hline
\end{tabular}

Keterangan:

P1: Persilangan puyuh jantan Hybrid dan betina Jepang (Coturnix coturnix japonica) (1:4)

P2: Persilangan puyuh jantan Hybrid dan betina Jepang (Coturnix coturnix japonica) (2:4)

P3: Persilangan puyuh jantan Hybrid dan betina Jepang (Coturnix coturnix japonica) (3:4)

P4: Persilangan puyuh jantan Hybrid dan betina Jepang (Coturnix coturnix japonica) (4:4)

Hasil perhitungan Benefit cost ratio (B/C) pada usaha pembibitan puyuh persilangan antara Coturnix-coturnix japonica dengan puyuh Hybrid mendapatkan nilai $\mathrm{B} / \mathrm{C}$ ratio pada perlakuan $\mathrm{P} 1$ dan $\mathrm{P} 2$ didapatkan nilai 0.4 , sedangkan pada perlakuan $\mathrm{P} 3$ dan $\mathrm{P} 4$ didapatkan nilai $\mathrm{B} / \mathrm{C}$ ratio 0.3. Nilai tersebut menunjukkan bahwa usaha ternak puyuh persilangan antara Coturnix coturnix japonica dengan Hybrid layak dan menguntungkan untuk dijadikan usaha. Hal itu disebabkan karena nilai $\mathrm{B} / \mathrm{C}$ ratio yang didapatkan lebih besar dari nol.

\section{KESIMPULAN}

Hasil analisa kelayakan usaha pembibitan ternak puyuh persilangan antara (Coturnix coturnix japonica) dengan Hybrid layak untuk dikembangkan, ditandai dengan mendapatkan nilai $\mathrm{R} / \mathrm{C}$ ratio lebih dari satu dan nilai $\mathrm{B} / \mathrm{C}$ ratio memberikan gambaran hasil yang menguntungkan serta usaha pembibitan puyuh persilangan Jepang (Coturnix coturnix japonica) dengan Hybrid menggunakan perlakuan P4

Analisis Usaha Pembibitan Puyuh persilangan Jepang (Coturnix coturnix japonica) 
mendapatkan nilai keuntungan total yang paling tinggi dibandingkan perlakuan yang lain. Oleh sebab itu, dapat dikatakan bahwa semakin banyak puyuh yang dipelihara maka akan semakin besar keuntungan yang didapatkan. .

\section{SARAN}

Melihat kondisi usaha pembibitan ternak puyuh persilangan antara Coturnix-coturnix japonica dengan Hybrid dengan menggunakan perlakuan P1, P2 ,P3 dan P4 mempunyai kemampuan tinggi secara analisis finansial dan pendapatan, maka usaha ini bisa menjadi salah satu usaha yang layak untuk dikembangkan dengan manajemen pemelihraan yang lebih baik lagi.

\section{DAFTAR PUSTAKA}

Anugerah, S, I. Iklin, S. Washyuning, K.S. 2009. Kebijakan kelembagaan usaha ternak unggas traditional sebagai sumber ekonomi rumah tangga pedesaan studi kasus Peternakan Burung Puyuh Yogyakarta. Jurnal Analisis Kebijakan Pertanian. 7: 249-276.(3).

Harahap, S. 2008. Perkembangan dan produktivitas lahan karet Indonesia. Balai Penelitian Sungai Putih.

Murib, P. I, Kruniasih. Kadarso.2014. Analisis ekonomi usaha ayam peterlur di Farm Harma Banjarhajo Kecamatan Ngemplak, Saleman. Jurnal Fakultas Pertanian Universitas Janabadra Yogyakarta. 16: 14-29.

Panekenan, O.J. J.C. Loing. B. Rorimpandey. dan P.O.V. Waleleng. 2013. Analisis Keuntungan Usaha Beternak Puyuh Di Kecamatan Sonder Kabupaten Minahasa. Jurnal Fakultas Peternakan. 32:1-10. (5).

Roessali, W. 2005. Profitabilitas Usaha Pembibitan Simental Di Kecamatan Candung Kabupaten Agam. Jurnal Pengembangan Peternakan Tropis. Special Edition Seminar nasional Ruminansia 7 oktober 2004 Buku 3. Fakultas Peternakan Universitas Diponogoro Semarang.

Zentiko B. D., M. Handayani dan S.I Santoso. 2015. Analisis break event point usaha peternakan ayam broiler di Kecamatan Limbangan Kabupaten Kendal. Jurnal. Faklutas Peternakan dan Pertanian Universitas Diponegoro. 4: 15-21 (1). 